'A Study of Aldred's Multiple Glosses to the Lindisfarne Gospels'. The Old English Gloss to the

Lindisfarne Gospels: Author, Language and Context. Eds Julia Fernández Cuesta and Sara M. Pons-

Sanz. Anglia Book Series 51. Berlin: de Gruyter, forthcoming. Expected date of publication: 2016.

\author{
Sara M. Pons-Sanz
}

\title{
A Study of Aldred's Multiple Glosses to the Lindisfarne Gospels
}

\begin{abstract}
Aldred, the glossator of the Lindisfarne Gospels, presents himself as carefully rendering the Latin lemmata in front of him, in terms of both their internal structure and meaning. His work includes a very high number of multiple glosses, which often attempt to clarify the polysemous character of a lemma or to provide additional information. This paper explores the multiple glosses including different lexemes which Aldred added to lexical lemmata in Mark's Gospel in an attempt to establish whether there is any correlation between Aldred's ordering practices and the frequency with which he used the interpretamenta to render those lemmata. The results of the study show some preference for placing the interpretamentum which most commonly renders the Latin lemma in first position, although Aldred's practice is not fully consistent.
\end{abstract}

\section{Introduction}

Aldred's Old English interlinear glosses to the Latin text of the Lindisfarne Gospels (London, British Library, MS Cotton Nero D.iv) have attracted significant attention from scholars interested in the history of the English language, not only in connection with what they can tell us about late Old Northumbrian, ${ }^{1}$ but also because of the features in their morphosyntax and lexis that associate them with much later texts, particularly texts from the transition from the Old to the early Middle English period. ${ }^{2}$ Aldred's glossing practices and techniques have also been scrutinized in order to gain a better understanding of issues as varied as his scholarly background or some of the possible purposes of the glosses. ${ }^{3}$ Amongst Aldred's glossing preferences one has often caught the attention of those studying his work: his clear propensity to use multiple interpretamenta to render a single Latin lemma. This feature of his work becomes particularly obvious when his glosses are compared with those by Owun to the Rushworth or MacRegol Gospels (Oxford, Bodleian Library, MS Auct. D.ii.19), because the

\footnotetext{
${ }^{1}$ For up-to-date work on the dialectal features of the glosses, see Fernández Cuesta and Rodríguez Ledesma (2007), and Fernández Cuesta et al. (2008).

${ }^{2}$ For recent studies on the morphosyntax of the glosses, see for instance, Millar (2000), where the glosses are a very significant part of the data under analysis, and Cole (2014), which focuses on the origins of the so-called Northern Subject Rule. On the Norse-derived terms recorded in the glosses, see Pons-Sanz (2000, 2004 and 2013).

${ }^{3}$ Boyd (1975a: 4-5, 8-10) points out that Aldred seems to have been particularly concerned with celibacy and simony. Brown (2003: 98-101) hypothesizes that, albeit a northerner, Aldred might have been educated south of the Humber, in the reforming circles associated with the Benedictine Reform; accordingly, his entering the community of St. Cuthbert might have had not only a spiritual purpose but also wider religious, social and even political aims, his use of English next to the Latin sacred text possibly hinting, as Brown indicates, at an attempt to support the 'Englishness' of the north in the face of contemporary Scandinavian activities. See, however, Rusche's paper (this volume).
} 
two sets of glosses are closely connected: ${ }^{4}$ Ross and Squires (1980: 494-495) count 543 double glosses in the section of the Rushworth Gospels glossed by Owun (i.e. Rushworth ${ }^{2}$ ), as opposed to 1,987 in the equivalent section of the Lindisfarne Gospels (or 1,846, if we exclude the double glosses recorded in the Lindisfarne contexts corresponding to lacunae in Rushworth $\left.{ }^{2}\right) .{ }^{5}$ On a number of occasions Aldred included even triple and quadruple glosses (Ross and Squires 1980: 490 count 106 and 8, respectively, in his work on the Lindisfarne Gospels and the Durham Collectar, Durham, Cathedral Library, MS A.iv.19). ${ }^{6}$

Aldred's multiple glosses vary greatly in the information they provide. While many of them simply present orthographic or grammatical alternatives (in terms of gender, case, simple vs. inflected infinitive, tense, mood, etc.), others include the use of synonyms or nearsynonyms, or the juxtaposition of an interpretamentum which directly corresponds to the Latin lemma and another one which interprets it in the light of its context. For instance, in MkGl (Li) 5.41 L puella is rendered as "dohter 1 mægden"; OE magden 'girl, maiden' is the term that normally renders the Latin lemma, while OE dohtor 'daughter' is included because the girl referred to is the daughter of the head of the synagogue, who has been introduced in MkGl (Li) 5.35 (see below, category B, under L puella, in the Appendix). ${ }^{7}$

While the use of such an impressive number of multiple glosses points towards Aldred's interest in linguistic issues, scholars are still unsure about how best to explain their presence in narrower terms. ${ }^{8}$ It is probably the case that there is more than one factor at work for his use of multiple glosses including different lexemes:

1) Uncertainty: it may be that Aldred was not sure about which Old English term best renders a Latin lemma, but this is not a very convincing explanation (certainly not for all cases) because very often a lemma that in some places receives a multiple gloss is on other occasions rendered by a single Old English interpretamentum.

2) Multiple sources: Aldred's multiple glosses might reflect the fact that he was working with different sources, which provided him with various alternatives for a single lemma. The possibility that he had access to Latin versions of the Gospels other than the text recorded in the Lindisfarne manuscript has long been argued for and accepted (see Ross 1981; and Kotake, this volume; see also DOE: s.v. bebeedan, sense C.2, on the use of OE bebeodan 'to command' as the interpretamentum for L comminari 'to threaten, menace' in MkGl (Li) $1.25){ }^{9}$

There are also various pieces of evidence suggesting that the Old English glosses are unlikely to be attributable to Aldred alone:

(a) It would be unusual for a glossator not to rely on other sources. As Stanton (2002: 12) points out, the transmission of glosses normally brings together tradition, in the form of a

\footnotetext{
${ }^{4}$ On the basis of the clear similarities between the two sets of glosses, scholars have traditionally accepted the hypothesis that Owun copied his glosses directly from Aldred's. However, this suggestion has been belied by Kotake's recent work; see his 2008a and 2008b articles, and his paper in this volume.

${ }^{5}$ On the relationship between the multiple glosses in Lindisfarne and Rushworth ${ }^{2}$, see also Pons-Sanz (2004).

${ }^{6}$ Aldred's enthusiasm for multiple glosses is not without parallels, though; for instance, Gretsch (1999: $49 \mathrm{n}$.

25) counts 1,400 double glosses, more than sixty triple glosses and three quadruple glosses in the Lambeth Psalter.

7 The meanings of Old English terms are given in accordance with the Dictionary of Old English (hereafter $D O E$ ) for the terms starting in any letter from $A$ to $G$, and with Clark Hall (1960), for the others. The title abbreviations and editions of the Old English texts mentioned in this paper are those employed by the Dictionary of Old English Web Corpus (hereafter DOEC). On the classification of Aldred's multiple glosses, see also Ross (1933b: 108).

${ }^{8}$ His interest in lexical matters is also manifested in his careful rendering of the structure of the Latin lemmata, to such an extent that, at times, we could characterize his gloss as rendering the Latin text morpheme by morpheme rather than just word by word.

${ }^{9}$ The meanings of Latin terms follow those provided by Lewis and Short (1879).
} 
received body of existing glosses, and innovation, as a result of the glossator's individual choices.

(b) The analysis of Aldred's hand has shown that it includes a wide range of letter forms and styles, which might reflect, at least partially, that he was copying from various exemplars (see Ker 1943; Brown 2003: 100; and Brookes's and Cole's papers in this volume).

(c) The glosses exhibit very significant linguistic variation in terms of phonology, spelling and morphosyntax which cannot be simply attributed to the fact that glossing the Lindisfarne Gospels is likely to have taken Aldred years rather than months. This is the topic of Cole's paper (this volume) and readers wanting to know more about this are directed there.

(d) Kotake (2012) has shown that Aldred changes his lexical practices in MtGl (Li) 26-28, a passage which shares many affinities with Farman's glosses to this section of the Rushworth Gospels (i.e. Rushworth ${ }^{1}$ ). Given that Farman's lexical practices when rendering particular terms here do not change in comparison with the rest of his work on the Rushworth Gospels, ${ }^{10}$ Kotake indicates that the traditional view that Farman was influenced by Aldred's work when glossing this section of Matthew's Gospel needs to be revised. If anything, the extant evidence argues in favour of the opposite direction of influence. Yet, Kotake is careful not to suggest a direct relation between the texts, as it may be that the two glossators resorted to a now-lost exemplar.

Yet, while it looks highly likely that Aldred had access to other Old English texts when doing his work, there is also evidence to suggest that Aldred did not slavishly follow an exemplar, but composed some of the glosses on his own as he went along (a practice fully in keeping with the interplay between tradition and innovation that Stanton refers to). For instance, in f. 174r the two syllables of L quinque 'five' are split between the third and fourth lines of the left column; Aldred initially glossed L quin- as OE "ðaðe", probably having taken it for the contracted negative relative pronoun L quin 'who not, but that' (L qui + no/ne), but he probably realized his mistake, as this form has been erased and OE fifo 'five' has been written on top of L quin- instead (see Ker 1957: 216).

3) Clarity: in the case of multiple glosses which include an interpretation (e.g. the glosses for L puella in MkGl (Li) 5.41 discussed above, p. $\mathbf{~}$ ), the main issue at work seems to have been an attempt to help understand particular Latin passages.

4) Lexicological and lexicographic concerns: with some of his multiple glosses Aldred may have been trying to produce "some sort of Roget's Thesaurus for Old English", as Gretsch (1999: 50) puts it in connection with the gloss to the Lambeth Psalter. ${ }^{11}$

5) Stylistic reasons: Stanton (2002: 52-53) hypothesizes that on some occasions (e.g. when the Latin lemma is rendered by various terms which alliterate) the multiple glosses might have been intended as stylistic models for poetry and prose. The influence of glossography on Old English literary language is suggested, for instance, by the fact that Byrhtferth relied very heavily in his Enchiridion on English interpretamenta recorded in the glosses to Aldhelm's De laude virginitatis (see Stanton 2002: 48). Even if the glosses did not generally set stylistic trends, we can assume that they were affected by collocations that were fairly common: for instance, L fidem (cp. L fides 'faith, belief') in MkArgGl (Li) 4 is rendered as "lufo 1 geleafo" and the union of these alliterating terms (viz. OE lufu 'love' and geleafa 'belief') is fairly

\footnotetext{
${ }^{10}$ For instance, Kotake (2012: 15) notes that Aldred renders L respondere 'to answer' consistently with OE andwyrdan up to $\mathrm{MtGl}$ (Li) 25.45, using OE andswarian only once (as the second interpretamentum in a double gloss; see MtGl (Li) 25.37). However, OE andswarian appears in the ten contexts where L respondere is recorded in MtGl (Li) 26-28, on two occasions with OE andwyrdan as an alternative (MtGl (Li) 26.23 and 27.12; cp. below, category A, under respondere, in the Appendix). Farman, on the other hand, uses both verbs throughout Matthew's Gospel, without any clear change in lexical preferences.

${ }^{11}$ See also Kuhn (1947: 168) and Kotake (2006b).
} 
common in Old English texts (see below, category B, under L fides, in the Appendix). ${ }^{12} \mathrm{We}$ find it, for instance, in a near-contemporary text of the glosses, viz. one of the Blickling homilies (late tenth century): "forðon pe nan wyrhta ne mæg god weorc wyrcean for Gode buton lufon \& geleafan" (HomU20 (BlHom10) 71-73; 'For no worker may perform good works before God without love and belief', as translated by Morris 1874: 110). We should not forget either that Old English writers were familiar with the use of hendiadys and amplification by means of synonyms as stylistic techniques (cp. Gretsch 1999: 50-51 and n. 28). However, such stylistic concerns have not always been accepted by scholars as significant factors in the work of glossators; for instance, Kuhn (1947: 168) argues that "considerations of clarity and accuracy, rather than any striving after rhetorical elegance, motivated the work of the glossators". ${ }^{3}$

\section{The present study}

\subsection{Aims of the study}

While the large number of multiple glosses in Aldred's work has long been acknowledged, there have not been many attempts to establish whether Aldred followed any particular patterns when ordering the interpretamenta in such glosses. As far as I am aware, this issue has only been dealt with in a handful of studies:

1) In an article focusing on Anglo-Scandinavian contact and its effects on the English language, Hines (1991: 410-411) mentioned in passing that "[a]lternative glosses placed in second place are unlikely to be words that should be less familiar to the reader [...] if anything, they should be more familiar, ensuring that the meaning is not missed or mistaken". 2) Hines made that comment in the context of Aldred's use of various Norse-derived terms in multiple glosses, an issue that I researched further in an article aiming to interpret Aldred's and Owun's Norse-derived terms from a sociolinguistic perspective in the light of their dialectal origins (Pons-Sanz 2004). The findings of my article have been problematized by Hogg's (2004) warning against the traditional interpretation of Aldred's language as representative of Northern Northumbrian and Owun's as exemplifying Southern Northumbrian, given that we do not know where the glossators came from and (in Owun's case) worked, and that some of the linguistic differences between the glosses might indicate spelling practices rather than phonological variation. Yet, the relevant findings for our present purposes still stand. The article records the following figures for John's Gospel:

(a) on 308 occasions (approx. 53\%), Owun's glosses correspond only to the first interpretamentum in a multiple Aldredian gloss;

(b) on 109 occasions (approx. 19\%), Owun's glosses correspond only to the second interpretamentum in a multiple Aldredian gloss;

(c) on 111 occasions (approx. 19\%), Owun's glosses correspond to Aldred's multiple glosses in terms of lexical choices and order;

\footnotetext{
12 On established word pairs in medieval English literature (frequently linked by phonetic devices such as alliteration, rhyme or assonance), see further Koskenniemi (1968).

${ }^{13}$ Another reason for the existence of multiple glosses might be that they are the work of different glossators. For instance, that is the case of the Vespasian Psalter, where most of the second glosses were added in the eleventh century to bring the original ninth-century gloss in line with the D-type gloss for each lemma (see Campbell 1967: 90-92). Yet, as far as the Lindisfarne Gospels are concerned, this is not likely to be an explanation for the multiple glosses because palaeographic evidence suggests that there was a single glossator (see Ross et al. 1960: 20; and Cole's and Brookes's papers in this volume).
} 
(d) on 11 occasions (approx. 2\%), Owun's glosses correspond to Aldred's multiple glosses in terms of lexical choices, but present a different order for the interpretamenta;

(e) on 39 occasions (approx. 7\%), Owun's lexical choices differ from Aldred's (Pons-Sanz 2004: 185).

If Owun and Aldred had access to the same or very similar multiple glosses (as it seems likely), these percentages would suggest that Owun found the first interpretamentum to be the most appropriate and the one that would be most helpful for his audience. Thus, this could be taken to imply (pace Hines) that the first rather than the second interpretamentum was the more familiar one.

3) In an article that is specifically devoted to ordering issues, Kotake (2006a) has explored some of the grammatical double glosses that Aldred used to translate Latin verbs. He has shown that Aldred tends to provide first what he calls literal translations, i.e. translations that are morphologically closer to the Latin lemma (e.g. a simple, i.e. non-periphrastic, verbal form to render the Latin imperfect and future, or a form in the subjunctive mood), and afterwards translations that differ from the lemma from a morphological perspective but which are possibly more idiomatic (e.g. the use of a periphrastic form with OE beon in the past + a present participle to render the Latin imperfect, or a verbal phrase with OE willan, sculan or magan to translate future and subjunctive forms). This would indicate that, as far as some grammatical glosses are concerned, Hines's assumption might be correct in the sense that the second gloss would be "more familiar, ensuring that the meaning is not missed or mistaken".

The present study aims to remedy, at least partially, the scarcity of studies on Aldred's ordering principles, particularly in connection with lexical rather than grammatical multiple glosses. If some consistency were to be found in Aldred's practice, the findings could be used to shed some light on various lexical issues. For instance, the Lindisfarne glosses exhibit a very high use of non-technical Norse-derived loans, unparalleled in (near-)contemporary texts (except for Rushworth ${ }^{2}$ ). This seems to point towards the close interaction between speakers of Old English and Old Norse and, perhaps, towards language shift by Old Norse speakers, as these loans might be the result of imposition rather than borrowing. ${ }^{14}$ Van Coetsem (1988: 3) distinguishes between the two mechanisms as follows:

If the recipient language speaker is the agent, as in the case of an English speaker using French words while speaking English, the transfer of material [...] from the source language to the recipient language is borrowing (recipient language agentivity). If, on the other hand, the source language speaker is the agent, as in the case of a French speaker using his French articulatory habits while speaking English, the transfer of material from the source language to the recipient language is imposition (source language agentivity).

Given that many of Aldred's Norse-derived terms appear in multiple glosses, ${ }^{15}$ the findings of this study might help us to evaluate the level of integration of the loans in the glosses and

\footnotetext{
${ }^{14}$ On the somewhat special character of the Norse-derived terms recorded in the Aldredian glosses and their use in multiple glosses, see Pons-Sanz (2013: 253-257).

15 For instance, in MkGl (Li) 14.15 we find a double gloss for L stratum: "song $\nmid$ bedd", where the first interpretamentum should be associated with OIc sang, saing 'bed' and OEN sang, siang, siang id. (see below, category C.2, under stratus, in the Appendix); the interpretamenta indicate that the Latin term has been misunderstood and has been interpreted, not as a form of the past participle of L sternere 'to prepare, spread', but as the related noun meaning 'bed'. See as well MkGl (Li) 15.11, where L concitare 'to rouse, excite' receives a double gloss with OE geeggian (cp. OIc eggja 'to egg on, incite') and geweccan (see below, category C.2, under concitare, in the Appendix); and MkGl (Li) 10.44 and 10.47, where L servus 'slave, servant' is
} 
could therefore lead to a better understanding of the lexical effects of Anglo-Scandinavian linguistic contact. The difficulty lies, of course, in establishing whose language the glosses reflect: Aldred's, his sources' or a mixture. Even though it seems almost undeniable that Aldred must have relied on other materials when carrying out his work, we should also bear in mind that his modus operandi shows sufficient sophistication for us to rule out the idea that he was merely a scribe slavishly following his sources. Like Owun, he had some control with regard to the terms he included in the gloss and the order in which they were presented. Therefore, it seems difficult to believe that his idiolect is not somehow represented by the lexical choices in the glosses.

\subsection{Data collection}

In order to carry out the present study on Aldred's ordering preferences, the following decisions have been made:

1) Given that Kotake (2006a) has already carried out some work on the ordering principles of double grammatical glosses and that there is no other equivalent work for the lexical glosses, this study focuses on multiple lexical glosses, from two perspectives: ${ }^{16}$

(a) it only examines cases where the glosses include different lexemes (except for the use of different forms of OE beon-wesan, which is the topic of Bolze's 2012 doctoral dissertation and her paper in this volume);

(b) it focuses on interpretamenta for Latin lexical words, not grammatical terms such as prepositions or conjunctions.

2) The multiple glosses are those recorded in Mark's Gospel, including the preliminary material in the Lindisfarne Gospels (the Argumentum and Capitula Lectionum). ${ }^{17}$ The selection of this particular Gospel responds to its controversial position in other linguistic studies: while Brunner (1947-1948) found clear spelling discrepancies between the glosses to Matthew's and Mark's Gospels up to MkGl (Li) 5.40 on the one hand, and those to the remainder of the Lindisfarne Gospels on the other, Cole's (2014 and this volume) findings on verbal morphosyntax do not support a clear-cut division between the initial chapters and the rest of Mark's Gospel. It was hoped that the present study might offer some additional information on the association of the glosses.

3) The study is based on Skeat's (1871-1887) edition of the Gospels, which is fully searchable in the DOEC; however, because of the inaccuracies of the edition (see Fernández Cuesta, this volume), an online reproduction of the Lindisfarne manuscript has also been accessed to check Skeat's readings and interpretations (see n. 6 in the Introduction). In his edition, Skeat consistently follows the order provided by Aldred for the interpretamenta in a multiple gloss wholly located directly above the Latin lemma, and, in those cases where the interpretamenta are not next to each other because one of them appears in the side margin, above or below, he gives as the first option the term that is directly above its lemma. ${ }^{18}$

rendered by OE pral (cp. OIc prall 'slave') and esne (see below, category C.3, under servus, in the Appendix). See also Ross and Squires (1980: 491) and above, p. $\mathbf{}$.

16 'Incomplete' multiple glosses, i.e. glosses where $t$ ( $\mathrm{L}$ vel 'or') is added but it is not followed by any interpretamentum, have not been considered in this study.

${ }^{17}$ The preliminary texts are abbreviated as MkArgGl (Li) and MkHeadGl (Li), respectively, in the DOEC.

18 See, for instance, f. 90v, where "sceortum", one of the interpretamenta for L breuia (cp. L brevis 'short'; MkArgGl (Li) 13), is written in the left-hand-side margin; f. 122v, where "twigge", one of the interpretamenta for L ramus 'branch, twig' (MkGl (Li) 13.28), is written in the top margin above the Latin text and its gloss; and f. 100v, where "forleten biðon", one of the interpretamenta for L dimittentur (cp. L dimittere 'to forgive; to send out, send forth, release'; MkGl (Li) 3.28), is written below its lemma. 
Thus, Mark's Gospel has initially been examined in order to identify the multiple glosses, and the Latin lemmata that receive multiple glosses have subsequently been searched in the Gospel using the DOEC in order to see how they are rendered on other occasions. As one might expect, there are some cases where a polysemous Latin lemma receives different interpretamenta according to the specific meaning in a context: for instance, when L dimittere means 'to let go, release, send forth', it is commonly rendered by OE forlatan (this is the only interpretamentum in fifteen out the eighteen attestations of the Latin verb with this meaning); however, when it means 'to forgive', it is most frequently rendered by $\mathrm{OE}$ forgiefan (this is the only interpretamentum in seven out the nine attestations of the Latin verb with this meaning; see below, categories B and C.3, under L dimittere, in the Appendix). ${ }^{19}$ Accordingly, the searches in the DOEC have not been carried out mechanically, but the meaning of the terms has also been checked against the Douay-Rheims Bible.

4) Even though in order to have as many instances of the Latin lemmata as possible it might have been tempting to include in the searches not only the specific Latin lexemes that receive one or more multiple glosses but also other members of their word-field, this course of action has not been taken because it is not always the case that members of the same word-field receive comparable interpretamenta. ${ }^{20}$ Sometimes the interpretamenta are simply different: for instance, L invenire 'to come upon, find, meet with' is rendered by OE mittan and findan, while L venire 'to come' is rendered by $\mathrm{OE}$ cuman (see below, category $\mathrm{B}$, under L invenire and venire, in the Appendix). On other occasions members of the same word-field receive similar interpretamenta but their frequencies of use differ. That is the case, for instance, for various members of the L ire 'to go, travel' word-field (L abire, ire, introire and praeterire), which are rendered in the main by OE gan, gangan, feran and faran (see below, the entries for these verbs in the different categories of the Appendix). The various members of an Old English word-field which render the same Latin intepretamentum are counted together, though. For instance, OE gangan and fromgangan as interpretamenta of L abire are counted together because the distinction between such forms is more appropriate for a paper concerned with the glosses from a morphological rather than a lexical perspective.

5) In the Appendix the multiple glosses have been classified into specific categories on the basis of the relationship between each of the interpretamenta that render the Latin lemma. Thus, for instance, L abire is associated with both category A ('cases where the first interpretamentum in a multiple gloss is the term that renders the Latin lemma most frequently in the Gospel') and category B ('cases where the first interpretamentum in a multiple gloss is not the term that renders the Latin lemma most frequently in the Gospel') because in one of the multiple glosses, viz. MkGl (Li) 1.35, OE feran, which renders the Latin verb on its own on four occasions, is followed by OE faran, which only renders the Latin verb in that context (category A), while in the other multiple gloss, viz. MkGl (Li) 7.30, OE feran is followed by OE gan, which renders the Latin verb on its own on seven occasions (category B).

\subsection{Results}

The process of data collection presented above has produced the following results. There are 261 pairs of words that appear in multiple glosses in Mark's Gospel. In 93 of those pairs (35.63\%) the first interpretamentum is the term that is most commonly used to translate the Latin lemma, while in 59 of the pairs $(22.60 \%)$ the more common interpretamentum to render

\footnotetext{
${ }^{19}$ OE forlatan could also mean 'to forgive, pardon' (see DOE: s.v. forlatan, sense 22), but this is not the verb that Aldred favoured in Lindisfarne to express that meaning.

20 'Word-field' here is used as a synonym of 'word family', i.e. it refers to a group of words formed by terms that share the same root, including compounds where one of the roots is the term under analysis.
} 
the Latin lemma does not appear in the first position. There is some uncertainty about the ordering patterns of 109 pairs (41.76\%; see further the Appendix). The reasons for such uncertainty are varied:

1) As far as 4 pairs of interpretamenta are concerned, it is difficult to determine whether they should be included in category A or B because the members of each pair render the lemma on the same number of occasions and, when the interpretamenta appear in a multiple gloss, they always do so in the same order: e.g. L traditio 'tradition' is rendered by a multiple gloss with OE selenes and setnes in that order on two occasions (MkGl (Li) 7.3 and 7.5) and each of the interpretamenta renders the lemma on its own on two occasions in Mark's Gospel. It is therefore difficult to determine which one might have been Aldred's preferred term to render the Latin lemma. It may be that such examples (category C.1 in the Appendix) represent common collocations, be it at a personal, dialectal or more general level. Indeed, it is interesting to note that some of the terms involved in such set glosses alliterate: viz. OE selenes and setnes, and OE telga and twig, which render L ramus 'branch, twig'. The above suggestion, though, is difficult to substantiate: of the terms involved in such set glosses, only OE telga and twig are found in collocations outside the Lindisfarne Gospels (and Rushworth $^{2}$ ), but they appear in the reverse order (see Dan 503 and 514). ${ }^{21}$ OE telga and twig, then, might have frequently occurred together but their order might not have been fully fixed. ${ }^{22}$

2) 83 pairs present a slight variation of the pattern explained above: the interpretamenta only co-occur in one multiple gloss and, if they occur in a single gloss, their number of occurrences is the same (category C.2 in the Appendix). For instance, L mendicare 'to beg, ask alms' is recorded twice in Mark's Gospel: it is rendered once by OE gyrnan (MkGl (Li) 10.46) and once by a double gloss with OE gegiwian and beodan (MkHeadGl (Li) 34).

3) 22 pairs appear in multiple glosses without a clear ordering pattern (category C.3 in the Appendix); e.g. L virtus 'strength, vigour' is rendered on twelve occasions by a single gloss: ten times by $\mathrm{OE}$ meaht and twice by OE magen; the two Old English terms render it together on two other occasions: in MkGl (Li) $9.1 \mathrm{OE}$ meaht is the first interpretamentum, whereas that position is taken by OE magen in MkGl (Li) 13.25.

These results indicate that Hines's (1991) aforementioned hypothesis (see above, p. cannot be unconditionally accepted because, if anything, the trend to place the interpretamentum that most commonly renders a Latin lemma in first position (category A) is stronger than the opposite trend (category B). The preference for placing the most common interpretamentum in first position applies even in contexts where the Latin lemma has a rather specific meaning that might be better rendered by an Old English term different from that which is most frequently used to translate it. For instance, OE wif is the most common interpretamentum for L uxor 'wife', but Aldred also renders the lemma with OE laf 'what is left, remnant; widow' on three occasions (viz. MkHeadGl (Li) 39, and MkGl (Li) 6.17 and 6.18) when it refers to the wife a dead man leaves behind; yet, even though that is the meaning of the lemma in MkGl (Li) 12.19, it is OE wif and not OE laf that appears in first position in a double gloss (see below, category A, under L uxor, in the Appendix). Similarly, L civitas 'city; citizenship, citizens united in a community' is always rendered by OE ceaster, either by itself or, on one occasion, as the first member in a multiple gloss, followed by $\mathrm{OE}$ burhwaru; in that context (MkGl (Li) 1.33), though, L civitas refers to the body politic, the citizens, and this is not a meaning commonly associated with OE ceaster, which refers to a

\footnotetext{
${ }^{21} \mathrm{Cp} . \mathrm{MkGl}$ (Li) 11.8, where the double gloss renders L frons 'leafy branch'. In the Arundel Psalter (PsGlJ (Oess) 79.12), OE telgor 'twig, branch', a member of the OE telge word-field, takes the first position in a similar double gloss.

${ }^{22}$ On reversible word pairs in Old and Middle English, see further Koskenniemi (1968: 81-88).
} 
place rather than its inhabitants, thus making OE burhwaru a better choice (the term renders L civis 'citizen' in LkGl (Li) 19.14; see below, category A, under L civitas, in the Appendix). Yet, as expected, Aldred's practice is not fully consistent: e.g. L comederunt (cp. L comedere 'to eat') in MkGl (Li) 4.4 is rendered as "fretton 1 eton"; in this context, which refers to birds, OE fretan might have been a better choice to capture the nuances of the context because it commonly collocates with animals or monsters whereas $\mathrm{OE}$ etan, the most common interpretamentum for the Latin lemma, is used more widely (see below, category B, under L comedere, in the Appendix; see also DOE: s.vv. etan and fretan; cp. Kotake 2006b: 63-66). Similarly, although OE ymbsellan, the verb that renders L circumdare 'to surround, place around' most often in the Lindisfarne gloss, ${ }^{23}$ is the only interpretamentum in MkGl (Li) 12.1, where it refers to a hedge placed around a vineyard, in MkGl (Li) 9.42 it follows OE ymbbindan in a reference to a millstone placed (or bound; cp. 'hanged' in the Douay-Rheims Bible) around someone's neck (see below, category B, under L circumdare, in the Appendix).

Thus, in general the results are not conclusive enough for them to be easily used in discussions about Aldred's lexicon of the sort mentioned above (see p. a). Consistency, as is widely known amongst scholars who have studied Aldred's works, was not his forte. ${ }^{24}$ However, pessimism should not be the dominant tone arising from this study. Looking so closely at Aldred's lexical choices allows us to identify some of his practices, and to explain some of the cases where he seems to deviate from his common practice of placing the most common Old English term (or word-field) that renders a Latin equivalent as the first interpretamentum in a multiple gloss:

1) The first interpretamentum in a multiple gloss tends to be formally and semantically closer to the Latin lemma, a trend that is in keeping with Kotake's (2006a) findings regarding Aldred's grammatical double glosses (see above, p. $\mathbf{m}$ ). Here are some examples:

(a) When the Latin lemma appears as well in a multiple gloss as a loanword, it tends to do so in first position: e.g. L tunicis (cp. L tunica 'under-garment, shirt, tunic') is rendered as "tunucum $\nmid$ cyrtlum" in MkGl (Li) 6.9, even though OE cyrtle is the term that Aldred chooses most commonly to render the Latin lemma (see below, category C.2, under L tunica, in the Appendix). Similarly, the OE bringan word-field is the most common choice to render L adferre 'to bring, carry' and ferre 'to bear, carry', but when the lemmata receive a double gloss in MkGl (Li) 1.32 and 2.3, respectively, a form of the similar-sounding OE ferian is placed in first position (see below, category $\mathrm{B}$, under L adferre and ferre, in the Appendix).

(b) On various occasions a Latin present participle acting as a nomen agentis is first glossed by a present participle and afterwards by a more idiomatic noun. For instance, in MkGl (Li) 4.3 the L seminans (cp. L seminare 'to sow'), which should be translated here as 'the one who sows, sower', is rendered as "sawende 1 sedere", where the first interpretamentum is the present participle of OE sawan and the second the agent noun OE sadere 'sower' (cp. OE sadian; see below, category A, under L seminare, in the Appendix). ${ }^{25}$ Interestingly, Aldred does use the verb OE saedian in MtGl (Li) 13.3, but he does not seem to have been very fond of it (even though a member of its word-field, viz. OE saed, is the term that most commonly renders L semen 'seed'), and OE sawan is the most common interpretamentum for L seminare instead. Thus, in this case we could say that Aldred is doing nothing other than

\footnotetext{
${ }^{23}$ The term is likely to be a loan-translation of the Latin verb, although it is not necessarily the case that Aldred (re-)coined it himself (see Waite 2014: 8).

${ }^{24}$ On Aldred's inconsistencies when glossing the Lindisfarne Gospels, see, for instance, Nagucka (1997) and Kotake (2006a). Scholars have also noted very clear disparities between Aldred's glosses to the Lindisfarne Gospels and those which he added to the Durham Collectar. See, for instance, Ross $(1970 ; 1978)$.

${ }^{25} \mathrm{Cp}$. MkGl (Li) 4.26, where L sementem (cp. L semens) receives the same double gloss; Aldred probably mistook this term for the present participle (see below, category C.2, under L semens, in the Appendix).
} 
putting the term that he uses most commonly to render the Latin verb in the initial position, but the same cannot be said about the following example: in MkHeadGl (Li) $20 \mathrm{~L}$ parentum (cp. L parens 'parent, progenitor'), originally a present participle form of L parire 'to bring forth, bear', is rendered as "strionendra 1 ældra", i.e. with a form of the present participle of OE streonan 'to beget, generate; gain, acquire' as the fist interpretamentum, even though $\mathrm{OE}$ ealdor is a much more common interpretamentum for the Latin lemma (see below, category $\mathrm{B}$, under L parens, in the Appendix).

(c) L videtur 'it seems' (cp. L videre 'to see, consider, know') in MkGl (Li) 14.64 is translated first by another simple verbal form with that meaning, viz. a form of OE pyncan 'to seem, appear' (viz. "ðyncge"). OE geseon 'to see', the verb that normally renders the Latin lemma, appears in second position in a passive construction (viz. "is gesene"), reflecting the Latin passive voice (see below, category B, under L videre, in the Appendix). This example tallies with Kotake's (2006a) findings in two respects: Aldred's preference for placing simple forms first followed by periphrastic forms, and his tendency, when rendering deponent verbs (i.e. verbs with a passive form but active meaning, which brings L videtur in this context close to them), to provide first an interpretamentum that renders the Latin meaning more precisely and then another which attempts to capture the passive form of the Latin lemma but which is either less natural or less appropriate from a semantic perspective. ${ }^{26}$

(c) When Aldred introduces a clarification or an interpretation of a Latin term based on the context, it does not tend to appear as the first member of a multiple gloss: see, for instance, MkGl (Li) 13.20, where L caro 'flesh' is rendered as "lichoma ł monn", OE lichama 'body' being the most common interpretamentum for the Latin lemma and OE mann 'person' having been introduced probably because the context refers as well to people who have been chosen to be saved (see below, category A, under L caro, in the Appendix). ${ }^{27}$ Similarly, in MkGl (Li) 5.2, when glossing L monumentum 'sepulchre, tomb', Aldred gives first OE byrgen, its most common interpretamentum, and then OE bend 'bond, fetters', most likely as a reference to the fact that we are told at the beginning of Mark's Gospel that the demon-possessed man that Christ encounters could not be restrained (cp. OE fastnung 'fastening, confinement' as the second interpretamentum in $\mathrm{MkGl}$ (Li) 5.5; see below, category A, under L monumentum, in the Appendix; and DOE: s.vv. bend, sense I.a.iv, and feestnung, sense 7). Yet, again, this is not always the case, an exception being, for instance, the aforementioned double gloss for $\mathrm{L}$ puella in MkGl (Li) 5.41 (see above, p. a).

2) Although not clearly connected with ordering practices, it is interesting to notice that there are various cases where Aldred appears to have changed his lexical preferences. For instance, Aldred's glossing habits for L accedere 'to come near, approach' seem to change in MkG1 (Li) 6: OE cuman and neahlacan, in that order, render the term in MkGl (Li) 1.31 and 6.21, but from then onwards $(\mathrm{MkGl}(\mathrm{Li}) 6.35,10.2,10.35,11.27,12.28,14.45)$ the term is only glossed with the latter interpretamentum (see below, category $\mathrm{B}$, under L accedere, in the Appendix). This is in line with what we see in the remainder of the Gospels: OE neahlaccan is clearly Aldred's preferred interpretamentum until MtGl (Li) 25 but, while it is still very prominent in $\mathrm{MtGl}(\mathrm{Li})$ 26-28, OE cuman gains significance there (see MtGl (Li) 26.7, 26.49, 26.60, 27.58). Interestingly, this change tallies with Kotake's (2012) findings concerning Aldred's lexical practices in these chapters (see above, p. $\mathbf{-})$. In Luke's and John's Gospels only OE neahlacan translates the Latin verb.

\footnotetext{
${ }^{26}$ Notably, though, L videtur with the same meaning in MtGl (Li) 18.11 and 22.42, and in LkGl (Li) 10.36 is rendered first by "is gesene" and then by a form of OE pyncan.

${ }^{27}$ The passage reads as follows in Douay-Rheims version of the Bible: "And unless the Lord had shortened the days, no flesh should be saved: but for the sake of the elect which he hath chosen, he hath shortened the days".
} 
It is, of course, difficult to know whether changes in lexical preferences are attributable to the influence of various sources, or more simply to the fact that Aldred had various (near-)synonyms in his lexical repertoire and his preferences changed over time (cp. Kotake 2008b). A much more thorough analysis of his lexical choices is needed before any answer, however tentative, can be given in this respect, although it is worth pointing out that this study can neither support nor refute a suggestion for a change in Aldred's sources around MkGl (Li) 5.

\section{Conclusion}

This paper has explored the multiple glosses including different lexemes which Aldred used to render Latin lexical lemmata in Mark's Gospel in an attempt to establish whether there is any correlation between Aldred's ordering practices and the frequency with which he used the interpretamenta to render those lemmata. The results of the study show some preference for placing the interpretamentum which most commonly renders the Latin lemma in first position, although Aldred's behaviour is not fully consistent. While the results might not allow us to make fully reliable inferences regarding the make-up of Aldred's lexicon on the basis of the position of a particular interpretamentum in a multiple gloss (either generally or specifically in terms of the Norse-derived terms recorded in the glosses), they do give us some insights into Aldred's ordering practices and lexical choices. In this respect, it is hoped that these findings may contribute to deepen our understanding of how Aldred carried out his work. ${ }^{28}$

\footnotetext{
${ }^{28}$ I am very thankful to Julia Fernández Cuesta, Susan Irvine, Tadashi Kotake and James Rawson for their comments on various versions of this paper. I would also like to thank the Spanish Ministry of Science and Technology (project FFI2011-28272) for its financial support.
} 


\section{Appendix}

\section{Multiple lexical glosses in Mark’s Gospel}

The interpretamenta for each Latin lemma have been arranged in terms of frequency. When two or more terms have the same frequency, they have been arranged alphabetically. $\mathrm{S}+\mathrm{a}$ number indicates the number of occurrences of the term in a single gloss; $M+$ a number indicates the number of occurrences of the term in a multiple gloss. Only the relevant interpretamenta and contexts are given in each case. Unless otherwise stated, the contexts referred to belong to the section of the text that the DOEC abbreviates as $\mathrm{MkGl}(\mathrm{Li})$.

A. Cases where the first interpretamentum in a multiple gloss is the term that renders the Latin lemma most frequently in the Gospel

\begin{tabular}{|c|c|c|c|}
\hline & Lemma & Interpretamenta & $\begin{array}{l}\text { Relevant } \\
\text { multiple } \\
\text { gloss(es) }\end{array}$ \\
\hline 1. & abire & $\operatorname{feran}(\mathrm{S} 4, \mathrm{M} 2), \operatorname{faran}^{29}(\mathrm{~S} 0, \mathrm{M} 1)$ & 1.35 \\
\hline 2. & adhuc & get (S 2, M 3), geona (S 1, M 2), leng (S 0, M 1) & 14.63 \\
\hline 3. & adsumere & niman (S 5, M 1), onfon (S 0, M 1) & 16.19 \\
\hline 4. & aiere & cwepan (S over 60, M 1), sop (S 0, M 1) & 11.31 \\
\hline 5. & amplius & forpor (S 2, M 3), mara (S 0, M 1) & 14.31 \\
\hline 6. & ascendere & (a)stigan (S 15, M 1), gan (S 0, M 1) & 4.7 \\
\hline 7. & aspicere & $(y m b)$ sceawian (S 0, M 2), seon (S 0, M 1) & 13.1 \\
\hline 8. & calix & calic (S 5, M 2), copp (S 0, M 1) & 9.41 \\
\hline 9. & calix & calic (S 5, M 2), disc (S 0, M 1) & 7.4 \\
\hline 10. & candidus & hwit ( S 2, M 1), lixian ( S 0, M 1) & 9.3 \\
\hline 11. & capere & niman (S 0, M 2), tellan (S 0, M 1) & 12.13 \\
\hline 12. & caro & lichama (S 7, M 1), mann (S 0, M 1) & 13.20 \\
\hline 13. & cena & feorm (S 2, M 1), symbel (S 0, M 1) & 6.21 \\
\hline 14. & cessare & blinnan (S 1, M 1), restan (S 0, M 1) & 4.39 \\
\hline 15. & civitas & ceastre (S 8, M 1), burhwaru (S 0, M 1) & 1.33 \\
\hline 16. & comminari & (belfor)beodan (S 3, M 1), stieran (S 0, M 1) & 8.30 \\
\hline
\end{tabular}

${ }^{29}$ On the relationship and overlap between OE faran and feran, see further Ogura (2002: 16-22). 


\begin{tabular}{|c|c|c|c|}
\hline & $\begin{array}{l}\text { ('to command, } \\
\text { charge, forbid') }\end{array}$ & & \\
\hline 17. & $\begin{array}{l}\text { comminari } \\
\text { ('to threaten, } \\
\text { meanace, rebuke') }\end{array}$ & stieran (S 4, M 1), (belfor)beodan (S 0, M 1) & 8.33 \\
\hline 18. & confestim & sona (S 5, M 2), hrape (S 0, M 1) & 4.17 \\
\hline 19. & conquirere & (efne)frignan (S 2, M 3), secan (S 1, M 2) & $9.14,12.28$ \\
\hline 20. & conquirere & (efne)frignan (S 2, M 3), frasian (S 0, M 1) & 9.16 \\
\hline 21. & conspuere & (efne)spittan (S 1, M 1), gehorwian (S 0, M 1) & 14.65 \\
\hline 22. & conturbare & styrian (S 0, M 2), dedrefan (S 0, M 1) & 9.20 \\
\hline 23. & convocare & (efne)cigan (S 5, M 1), clipian (S 0, M 1) & 8.34 \\
\hline 24. & curare & geman (S 5, M 2), haelan (S 0, M 1) & 6.5 \\
\hline 25. & deprecari & biddan (S 6, M 1), geornian (S 0, M 1) & 1.40 \\
\hline 26. & descendere & (ofladun)stigan (S 5, M 1), cuman (S 0, M 1) & 3.22 \\
\hline 27. & dicere & cwepan (S over 100, M 3), secgan (S 8, M 2) & $7.36,8.26$ \\
\hline 28. & dicere & cwepan (S over 100, M 3), nemnan (S 0, M 1) & 15.7 \\
\hline 29. & diversus & ungelic (S 0, M 2), monigfeald (S 0, M 1) & $\begin{array}{l}\text { MkHeadGl } \\
\text { (Li) } 9\end{array}$ \\
\hline 30. & diversus & $\begin{array}{l}\text { ungelic (S 0, M 2), beorht (S 0, M 1), } \\
\text { fagung (S 0, M 1) }\end{array}$ & $\begin{array}{l}\text { MkHeadGl } \\
\text { (Li) } 42\end{array}$ \\
\hline 31. & donec & oppat (S 3, M 3), pa hwil (S 0, M 1) & 14.32 \\
\hline 32. & educere & (of)ladan (S 2, M 1), ateon (S 0, M 1) & 14.47 \\
\hline 33. & egredi & feran $(\mathrm{S} 7, \mathrm{M} 3)$, faran $(\mathrm{S} 4, \mathrm{M} 3)$ & $1.35,8.27,13.1$ \\
\hline 34. & eicere & (for)drifan (S 8, M 3), afirran (S 0, M 1) & 1.34 \\
\hline 35. & emere & bycgan (S 1, M 1), ceapian (S 0, M 1) & 6.36 \\
\hline 36. & exoriri & $\operatorname{arisan}(\mathrm{S} 0, \mathrm{M} 2)$, upgan $(\mathrm{S} 0, \mathrm{M} 1)$ & 4.6 \\
\hline 37. & generatio & cneores (S 4, M 1), peod (S 0, M 1) & 8.12 \\
\hline 38. & gens ('nation') $)^{30}$ & cynn (S 4, M 1), hapen (S 0, M 1) & 13.10 \\
\hline
\end{tabular}

\footnotetext{
${ }^{30}$ On the glosses to L gens, see further Kotake (2006b).
} 


\begin{tabular}{|c|c|c|c|}
\hline 39. & gustare & birgan (S 1, M 1), supan (S 0, M 1) & $\begin{array}{l}\text { MkHeadGl } \\
\text { (Li) } 27\end{array}$ \\
\hline 40. & hora & $\operatorname{tid}(\mathrm{S} 9, \mathrm{M} 1), h w i l(\mathrm{~S} 0, \mathrm{M} 1)$ & 13.32 \\
\hline 41. & iam & gea (S 4, M 3), hwaepere (S 0, M 1) & 15.44 \\
\hline 42. & ianua & duru (S 2, M 1), geat (S 0, M 1) & 1.33 \\
\hline 43. & ingredi & ingan (S 1, M 2), inferan (S 0, M 1) & 1.21 \\
\hline 44. & ingredi & ingan (S 1, M 2), ingangan (S 0, M 1) & 3.27 \\
\hline 45. & inquirere & cwepan (S 1, M 1), secgan (S 0, M 1) & 12.26 \\
\hline 46. & introire & (in)gangan (S 0, M 5), incuman (S 0, M 1) & 1.45 \\
\hline 47. & lignum & steng (S 1, M 1), treow (S 0, M 1) & 14.43 \\
\hline 48. & ire & gan (S 6, M 2), (forlfrom)gangan (S 3, M 2) & $1.38,14.42$ \\
\hline 49. & locus & stow (S 5, M 1), stede (S 0, M 1) & 1.35 \\
\hline 50. & lucerna & leoht(fat) (S 1, M 1), pacele (S 0, M 1) & 4.21 \\
\hline 51. & mane & arlice (S 2, M 1), on morgen (S 0, M 1) & 16.9 \\
\hline 52. & manifestare & (aet)eawan (S 1, M 1), marsian (S 0, M 1) & 3.12 \\
\hline 53. & mittere & sendan (S 34, M 1), faran (S 0, M 1) & 4.37 \\
\hline 54. & mons & $\operatorname{mor}(\mathrm{S} 9, \mathrm{M} 1), d u n(\mathrm{~S} 0, \mathrm{M} 1)$ & 13.3 \\
\hline 55. & monumentum & byrgen (S 8, M 2), bend (S 0, M 1) & 5.2 \\
\hline 56. & monumentum & byrgen (S 8, M 2), fastnung (S 0, M 1) & 5.5 \\
\hline 57. & omnis & aghwilc (S 3, M 3), anig (S 0, M 1) & 13.20 \\
\hline 58. & oportere & sculan (S 0, M 2), becuman (S 0, M 1) & 14.31 \\
\hline 59. & pars & deel (S 1, M 1), land (S 0, M 1) & 8.10 \\
\hline 60. & percutere & (burh)slean (S 2, M 1), hrinan (S 0, M 1) & 14.27 \\
\hline 61. & perdere & losian (S 9, M 1), fordon (S 0, M 1) & 9.22 \\
\hline 62. & peregre & feor (S 1, M 1), long waeg (S 0, M 1) & 13.34 \\
\hline 63. & petere & giwian (S 7, M 1), wilnian (S 2, M 1) & 6.22 \\
\hline 64. & porcus & bearg (S 4, M 1), swin (S 0, M 1) & 5.11 \\
\hline
\end{tabular}




\begin{tabular}{|c|c|c|c|}
\hline 65. & potestas & meaht (S 11, M 1), onweald (S 0, M 1) & 13.34 \\
\hline 66. & praecedere & foregan (S 1, M 1), onforan gangan (S 0, M 1) & 10.32 \\
\hline 67. & praedicare & (fore)bodian (S 15, M 2), foresecgan (S 0, M 2) & $6.12,13.10$ \\
\hline 68. & procedere & feran $(\mathrm{S} 0, \mathrm{M} 2)$, springan $(\mathrm{S} 0, \mathrm{M} 1)$ & 1.28 \\
\hline 69. & procidere & (fore)feallan (S 3, M 2), hleotan (S 0, M 2) & $3.11,5.22$ \\
\hline 70. & (peregre) profici & feran (S 1, M 3), elpeodian (S 0, M 1) & 13.34 \\
\hline 71. & quantus & hu micel (S 3, M 1), swalhu lenge (S 1, M 1) & 9.21 \\
\hline 72. & quidem & eac (S 2, M 1), soplice (S 0, M 1) & 16.19 \\
\hline 73. & relinquere & (for)letan (S 10, M 2), laefan (S 0, M 2) & $12.19,12.20$ \\
\hline 74. & respondere & (ge)andwyrdan (S 33, M 1), (ge)andswarian (S 8, M 1) & 14.14 \\
\hline 75. & scandalizare & andspurnan (S 8, M 1), todrifan (S 0, M 1) & 14.27 \\
\hline 76. & (ne)scire & witan (S 26, M 2), cunnan (S 0, M 2) & $12.24,14.71$ \\
\hline 77. & semen & $\operatorname{secd}(\mathrm{S} 4, \mathrm{M} 2)$, team $(\mathrm{S} 0, \mathrm{M} 2)$ & $12.21,12.22$ \\
\hline 78. & seminare & sawan (S 11, M 1), sadere (S 0, M 1) & 4.3 \\
\hline 79. & sero & aefen(tid) (S 2, M 2), smolt/smyltnes (S 0, M 2) & $4.35,6.47$ \\
\hline 80. & signum & beacen (S 6, M 2), tacn (S 0, M 3) & $\begin{array}{l}\text { MkHeadGl } \\
\text { (Li) 24; 14.44, } \\
16.19\end{array}$ \\
\hline 81. & sporta & $\operatorname{cawl}(\mathrm{S} 1, \mathrm{M} 1), \operatorname{mand}(\mathrm{S} 0, \mathrm{M} 1)$ & 8.20 \\
\hline 82. & sufferre & $\operatorname{niman}(\mathrm{S} 2, \mathrm{M} 1), \operatorname{beran}(\mathrm{S} 0, \mathrm{M} 1)$ & 8.19 \\
\hline 83. & transferre & oferferian (S 1, M 1), beleoran (S 0, M 1) & 14.36 \\
\hline 84. & synagoga & samnung (S 9, M 1), sprace (S 0, M 1) & 6.2 \\
\hline 85. & talis & puslic (S 3, M 1), swilc (S 0, M 1) & 13.19 \\
\hline 86. & temptare & acunnian (S 3, M 1), costian (S 0, M 1) & 10.2 \\
\hline 87. & tempus & tid (S 5, M 3), hwil (S 0, M 1) & 2.19 \\
\hline 88. & tempus & $\operatorname{tid}(\mathrm{S} 5, \mathrm{M} 3)$, fyrst (S 0, M 1) & 9.21 \\
\hline 89. & tempus & $\operatorname{tid}(\mathrm{S} 5, \mathrm{M} 3), \operatorname{lif}(\mathrm{S} 0, \mathrm{M} 1)$ & 10.30 \\
\hline 90. & tollere & niman (S 7, M 3), beran (S 0, M 2) & $2.9,2.11$ \\
\hline
\end{tabular}




\begin{tabular}{|c|l|l|l|}
\hline 91. & uxor & wif (S 8, M 1), laf (S 3, M 1) & 12.19 \\
\hline 92. & vestimentum & waed (S 9, M 1), hragl (S 3, M 1), clap (S 0, M 1) & 14.63 \\
\hline 93. & videre & geseon (S over 70, M 2), behealdan ( S 0, M 1) & 13.9 \\
\hline
\end{tabular}

B. Cases where the first interpretamentum in a multiple gloss is not the term that renders the Latin lemma most frequently in the Gospel

\begin{tabular}{|c|c|c|c|}
\hline & Lemma & Interpretamenta & $\begin{array}{c}\text { Relevant } \\
\text { multiple } \\
\text { gloss(es) }\end{array}$ \\
\hline 1. & abire & $\operatorname{gan}(\mathrm{S} 7, \mathrm{M} 1)$, feran $(\mathrm{S} 4, \mathrm{M} 2)$ & 7.30 \\
\hline 2. & accedere & neahlacan (S 6, M 2), cuman (S 0, M 2) & $1.31,6.21$ \\
\hline 3. & adferre & (to)bringan (S 8, M 1), ferian (S 0, M 1) & 1.32 \\
\hline 4. & adprehendere & lacan (S 4, M 1), gegripan (S 1, M 1) & 7.33 \\
\hline 5. & amputare & ceorfan (S 1, M 1), sncedan (S 0, M 1) & 14.47 \\
\hline 6. & aspicere & $(y m b)$ sceawian (S 0, M 2), uplocian (S 0, M 1) & 8.24 \\
\hline 7. & brevia/breviter & sceort (S 1, M 1), lytel (S 0, M 1) & $\begin{array}{l}\text { MkArgGl } \\
\text { (Li) } 13\end{array}$ \\
\hline 8. & capere & $\operatorname{niman}(\mathrm{S} 0, \mathrm{M} 2)$, fon $(\mathrm{S} 0, \mathrm{M} 1)$ & 2.2 \\
\hline 9. & circumdare & ymbsellan (S 1, M 1), ymbbindan (S 0, M 1) & 9.42 \\
\hline 10. & circumspicere & ymbsceawian (S 3, M 1), ymblocian (S 2, M 1) & 3.34 \\
\hline 11. & comedere & etan (S 2, M 1), fretan (S 0, M 1) & 4.4 \\
\hline 12. & complexari & frigian (S 1, M 1), clyppan (S 0, M 1) & 9.36 \\
\hline 13. & confestim & sona $(\mathrm{S} 5, \mathrm{M} 2)$, recene $(\mathrm{S} 0, \mathrm{M} 1)$ & 5.29 \\
\hline 14. & contemnere & $\begin{array}{l}\text { niperian }(\mathrm{S} 1, \mathrm{M} 1), \text { hinan }(\mathrm{S} 0, \mathrm{M} 1) \text {, } \\
\text { tellan }(\mathrm{S} 0, \mathrm{M} 1)\end{array}$ & 9.12 \\
\hline 15. & conturbare & styrian (S 0, M 2), unrotsian (S 0, M 1) & 6.50 \\
\hline 16. & convertere & (efne)cierran (S 3, M 1), hweorfan (S 0, M 1) & 4.12 \\
\hline 17. & convincere & (efne)cierran (S 1, M 1), ofercuman (S 0, M 1) & $\begin{array}{l}\text { MkHeadGl } \\
\text { (Li) } 37\end{array}$ \\
\hline
\end{tabular}




\begin{tabular}{|c|c|c|c|}
\hline 18. & curare & geman (S 5, M 1), lacnian (S 0, M 1) & 1.34 \\
\hline 19. & deinde & aefterpon (S 2, M 1), sope (S 1, M 1) & 4.17 \\
\hline 20. & difficilis & hefig (S 1, M 1), uneape (S 0, M 1) & 10.23 \\
\hline 21. & $\begin{array}{l}\text { dimittere } \\
\text { ('to let go, } \\
\text { release, send } \\
\text { forth') }\end{array}$ & forlatan (S 15, M 1), forgiefan (S 2, M 1) & 15.9 \\
\hline 22. & diripere & reafian $(\mathrm{S} 1, \mathrm{M} 1), \operatorname{niman}(\mathrm{S} 0, \mathrm{M} 1)$ & 3.27 \\
\hline 23. & dives & wlanc (S 1, M 2), welig (S 0, M 2) & $10.25,12.41$ \\
\hline 24. & docere & laeran (S 20, M 1), taecan (S 0, M 1) & 12.38 \\
\hline 25. & donec & oppat (S 3, M 3), wi $p$ (S 0, M 2) & $\begin{array}{l}\text { MkHeadGl } \\
\text { (Li) } 27 ; 6.10\end{array}$ \\
\hline 26. & exclamare & (of)clypian (S 5, M 1), ciegan (S 0, M 1) & 6.49 \\
\hline 27. & exoriri & arisan (S 0, M 2), upiernan (S 0, M 1) & 4.5 \\
\hline 28. & expirare & asweltan (S 1, M 1), gast agiefan (S 0, M 1) & 15.37 \\
\hline 29. & ferre & bringan (S 1, M 1), ferian (S 0, M 1) & 2.3 \\
\hline 30. & fides & geleafa (S 7, M 1), lufu (S 0, M 1) & $\begin{array}{l}\text { MkArgGl } \\
\text { (Li) } 4\end{array}$ \\
\hline 31. & fretum & luh (S 3, M 1), sweora (S 0, M 1) & 5.1 \\
\hline 32. & iam & witodlic (S 3, M 1), hwil (S 0, M 1) & 5.3 \\
\hline 33. & indigne & unweorpe (S 1, M 1), belgan (S 0, M 1) & 14.4 \\
\hline 34. & invenire & (on/in)findan (S 5, M 1), gemittan (S 4, M 1) & 7.30 \\
\hline 35. & lectio & raede $(\mathrm{S} 1, \mathrm{M} 1), \operatorname{lar}(\mathrm{S} 0, \mathrm{M} 1)$ & $\begin{array}{l}\text { MkArgGl } \\
\text { (Li) } 2\end{array}$ \\
\hline 36. & minister & embehtmann (S 3, M 1), hera (S 0, M 1) & 10.43 \\
\hline 37. & multus & manig (S 38, M 4), micel (S 3, M 1) & 4.5 \\
\hline 38. & nihil & naht (S 3, M 1), aniht (S 0, M 1) & 15.5 \\
\hline 39. & $\begin{array}{l}\text { novissimel } \\
\text { novissium }\end{array}$ & latemest (S 0, M 2), at ende (S 0, M 1) & 12.6 \\
\hline 40. & novissimel & latemest (S 0, M 2), at neahste (S 0, M 1) & 16.14 \\
\hline
\end{tabular}




\begin{tabular}{|c|c|c|c|}
\hline & novissium & & \\
\hline 41. & oboedire & $\begin{array}{l}\text { edmodigan (S 1, M 1), hieran (S 0, M 1), } \\
\text { hyrsumian (S 0, M 1) }\end{array}$ & 4.41 \\
\hline 42. & parabola & bispell (S 12, M 1), bisen (S 0, M 1) & 4.34 \\
\hline 43. & parens & ealdor (S 1, M 1), streonend (S 0, M 1) & $\begin{array}{l}\text { MkHeadGl } \\
\text { (Li) } 20\end{array}$ \\
\hline 44. & praecipere & beodan (S 8, M 1), hatan (S 6, M 1) & 9.9 \\
\hline 45. & praeterire & bifaran (S 1, M 1), bigangan (S 0, M 1) & 15.21 \\
\hline 46. & procedere & feran (S 0, M 2), faran (S 0, M 1) & 14.35 \\
\hline 47. & proximus & neah (S 5, M 1), unfearr (S 0, M 1) & 13.29 \\
\hline 48. & puella & maegden (S 9, M 1), dohtor (S 0, M 1) & 5.41 \\
\hline 49. & sabbatum & sunnandag (S 6, M 1), haligdacg (S 1, M 1) & 6.2 \\
\hline 50. & salutare & gretan (S 2, M 1), wilcumian (S 0, M 1) & 12.38 \\
\hline 51. & singulus & syndrig (S 1, M 1), an (S 0, M 1) & $\begin{array}{l}\text { MkArgGl } \\
\text { (Li) } 5\end{array}$ \\
\hline 52. & statim & sona $(\mathrm{S} 22, \mathrm{M} 1), \operatorname{recen}(\mathrm{S} 4, \mathrm{M} 1)$ & 9.20 \\
\hline 53. & summum & heah(nes) (S 0, M 2), brerd (S 0, M 1) & 13.27 \\
\hline 54. & summum & heah(nes) (S 0, M 2), hrof(S 0, M 1) & 13.27 \\
\hline 55. & turba & preat (S 22, M 1), here (S 1, M 1) & 4.36 \\
\hline 56. & tollere & niman (S 7, M 3), laedan (S 0, M 1) & 6.8 \\
\hline 57. & venire & cuman (S over 80, M 1), mittan (S 0, M 1) & 11.13 \\
\hline 58. & vexare & beran (S 1, M 1), awalan (S 1, M 1) & 5.18 \\
\hline 59. & videre & geseon (S over 70, M 2), pyncan (S 0, M 1) & 14.64 \\
\hline
\end{tabular}

C. Uncertain cases

C.1 Set order

\begin{tabular}{|c|c|c|c|}
\hline Lemma & Interpretamenta & $\begin{array}{l}\text { Relevant } \\
\text { multiple } \\
\text { gloss(es) }\end{array}$ \\
\hline
\end{tabular}




\begin{tabular}{|c|l|l|l|}
\hline 1. & accusare & tellan (S 0, M 2), niperian (S 0, M 2) & $\begin{array}{l}\text { MkHeadG1 } \\
(\mathrm{Li}) 20 ; 3.2\end{array}$ \\
\hline 2. & modium & mitta $(\mathrm{S}$ 0, M 2), faet (S 0, M 2) & $\begin{array}{l}\text { MkHeadG1 } \\
(\mathrm{Li}) 12 ; 4.21\end{array}$ \\
\hline 3. & ramus & telga $(\mathrm{S} \mathrm{0,} \mathrm{M} \mathrm{2),} \mathrm{twig} \mathrm{(S} \mathrm{0,} \mathrm{M} \mathrm{2)}$ & $4.32,13.28$ \\
\hline 4. & traditio & selenes (S 2, M 2), setnes (S 2, M 2) & $7.3,7.5$ \\
\hline
\end{tabular}

C.2 Only one multiple gloss (with those terms)

\begin{tabular}{|c|c|c|c|}
\hline & Lemma & Interpretamenta & $\begin{array}{l}\text { Relevant } \\
\text { multiple } \\
\text { gloss(es) }\end{array}$ \\
\hline 1. & abundare & manigfealdan (S 0, M 1), weaxan (S 0, M 1) & 12.44 \\
\hline 2. & adicere & geeacnian (S 0, M 1), sellan (S 0, M 1) & 4.24 \\
\hline 3. & adlidere & begitan (S 0, M 1), toslitan (S 0, M 1) & 9.18 \\
\hline 4. & aedificatio & gleng (S 0, M 1), geren (S 0, M 1) & 13.2 \\
\hline 5. & afficere & acwellan (S 0, M 1), fordon (S 0, M 1) & 13.12 \\
\hline 6. & amicere & gegearwian (S 0, M 1), ymbgyrdan (S 0, M 1) & 14.51 \\
\hline 7. & amputare & tellan (S 0, M 1), clansian (S 0, M 1) & $\begin{array}{l}\text { MkArgGl } \\
\text { (Li) } 15\end{array}$ \\
\hline 8. & caecatus & blind (S 0, M 1), peostrig (S 0, M 1) & 8.17 \\
\hline 9. & capitulum & $\begin{array}{l}\text { forecwide (S 0, M 1), foremearcung (S 0, M 1), } \\
\text { heafodweard (S 0, M 1) }\end{array}$ & $\begin{array}{l}\text { MkArgGl } \\
\text { (Li) } 1\end{array}$ \\
\hline 10. & colaphus & dynt (S 0, M 1), fyst (S 0, M 1) & 14.65 \\
\hline 11. & comminuere & forbrecan (S 0, M 1), toscanan (S 0, M 1) & 5.4 \\
\hline 12. & committere & efenesendan (S 0, M 1), geendian (S 0, M 1) & 10.11 \\
\hline 13. & concidere & feallan (S 0, M 1), perscan (S 0, M 1) & 5.5 \\
\hline 14. & concitare & geeggian (S 0, M 1), geweccan (S 0, M 1) & 15.11 \\
\hline 15. & dehinc & aefter pon (S 0, M 1), sippa (S 0, M 1) & $\begin{array}{l}\text { MkArgGl } \\
\text { (Li) } 5\end{array}$ \\
\hline 16. & dепио & niwunga $(\mathrm{S} 0, \mathrm{M} 1)$, sona $(\mathrm{S} 0, \mathrm{M} 1)$ & 14.14 \\
\hline
\end{tabular}




\begin{tabular}{|c|c|c|c|}
\hline 17. & deorsum & geanpe (S 0, M 1), sundrig (S 0, M 1) & 11.46 \\
\hline 18. & destruere & tostregdan (S 0, M 1), towearpan (S 0, M 1) & 13.2 \\
\hline 19. & (dies) festus & barlic (S 0, M 1), (dag) halig (S 0, M 1) & 14.2 \\
\hline 20. & discumbere & hlinian (S 0, M 1), restan (S 0, M 1) & 2.15 \\
\hline 21. & disputare & flitan (S 0, M 1), tellan (S 0, M 1) & 9.34 \\
\hline 22. & disserere & $\begin{array}{l}\text { secgan (S 0, M 1), tosceadan (S 0, M 1), } \\
\text { trahtian (S 0, M 1) }\end{array}$ & 4.34 \\
\hline 23. & dissolvere & toslitan (S 0, M 1), undon (S 0, M 1) & 14.58 \\
\hline 24. & domare & healdan (S 0, M 1), temian (S 0, M 1) & 5.4 \\
\hline 25. & domicilium & hus (S 0, M 1), lytel hus (S 0, M 1) & 5.3 \\
\hline 26. & eventura & gelimpan sculan (S 0, M 1), toweard (S 0, M 1) & 10.32 \\
\hline 27. & evertere & ofcierran (S 0, M 1), utdrifan (S 0, M 1) & 11.15 \\
\hline 28. & exaestuare & gedrugian (S 0, M 1), forbarnan (S 0, M 1) & 4.6 \\
\hline 29. & excutere & drygan (S 0, M 1), sceadan (S 0, M 1) & 6.11 \\
\hline 30. & exprobare & forcuman (S 0, M 1), fordrifan (S 0, M 1) & 16.14 \\
\hline 31. & exprobare & forcwepan (S 0, M 1), teelan (S 0, M 1) & $\begin{array}{l}\text { MkHeadGl } \\
\text { (Li) } 39\end{array}$ \\
\hline 32. & figuraliter & gastlice (S 0, M 1), magwlitlice (S 0, M 1) & $\begin{array}{l}\text { MkHeadGl } \\
\text { (Li) } 40\end{array}$ \\
\hline 33. & frons & telga (S 0, M 1), twig (S 0, M 1) & 11.8 \\
\hline 34. & galli cantus & hancred (S 0, M 1), uhttid (S 0, M 1) & 13.35 \\
\hline 35. & grandis & swipe (S 0, M 1), micel (S 0, M 1) & 14.15 \\
\hline 36. & habitare & buan (S 0, M 1), wunian (S 0, M 1) & 4.32 \\
\hline 37. & harundo & gierd (S 0, M 1), hreod (S 0, M 1) & 15.19 \\
\hline 38. & holus & graes (S 0, M 1), wyrt (S 0, M 1) & 4.32 \\
\hline 39. & imitare & gebysnian (S 0, M 1), gelician (S 0, M 1) & $\begin{array}{l}\text { MkHeadGl } \\
\text { (Li) } 32\end{array}$ \\
\hline 40. & immolare & agiefan (S 0, M 1), asecgan (S 0, M 1) & 14.12 \\
\hline
\end{tabular}




\begin{tabular}{|c|c|c|c|}
\hline 41. & impetus & ongean (S $0, \mathrm{M} 1)$, raes $(\mathrm{S} 0, \mathrm{M} 1)$ & 5.13 \\
\hline 42. & ingemescere & gemanan (S 0, M 1), seofian (S 0, M 1) & 8.12 \\
\hline 43. & ingravatus & hefig (S 0, M 1), pislic (S 0, M 1) & 14.40 \\
\hline 44. & iniquis & unrihtwis (S 0, M 1), wohful (S 0, M 1) & 15.28 \\
\hline 45. & $\begin{array}{l}\text { inquam } \\
\text { (defective) }\end{array}$ & cwepan (S 0, M 1), secgan (S 0, M 1) & 12.26 \\
\hline 46. & inquirere & gefrignan (S 0, M 1), gesecan (S 0, M 1) & $\begin{array}{l}\text { MkArgGl } \\
\text { (Li) } 5\end{array}$ \\
\hline 47. & leprosus & hreof (S 0, M 1), licprowere (S 0, M 1) & $\begin{array}{l}\text { MkHeadGl } \\
\text { (Li) } 5\end{array}$ \\
\hline 48. & locare & agiefan (S 0, M 1), gefaestan (S 0, M 1) & 12.1 \\
\hline 49. & ludere & bismerian (S 0, M 1), taelan (S 0, M 1) & 15.31 \\
\hline 50. & mendicare & beodan (S 0, M 1), gegiwian (S 0, M 1) & $\begin{array}{l}\text { MkHeadGl } \\
\text { (Li) } 34\end{array}$ \\
\hline 51. & mystice & deoplice (S 0, M 1), runlice (S 0, M 1) & $\begin{array}{l}\text { MkHeadGl } \\
\text { (Li) } 44\end{array}$ \\
\hline 52. & necessarius & behoflic (S 0, M 1), nydpearf (S 0, M 1) & 11.3 \\
\hline 53. & nudare & genacodian (S 0, M 1), unpeccan (S 0, M 1) & 2.4 \\
\hline 54. & numquid & $a h(\mathrm{~S} 1, \mathrm{M} 1)$, hwaeper (S 1, M 1) & 4.21 \\
\hline 55. & occaecatus & foreblind (S 0, M 1), forepeostrian (S 0, M 1) & 6.52 \\
\hline 56. & opinio & maersung (S 0, M 1), wena (S 0, M 1) & 13.7 \\
\hline 57. & oportere & beon riht(lic) (S 1, M 1), sculan (S 0, M 2) & 13.7 \\
\hline 58. & penuria & hienp (S 0, M 1), unsped (S 0, M 1) & 12.44 \\
\hline 59. & pera & pohha (S 0, M 1), pusa (S 0, M 1) & 6.8 \\
\hline 60. & perfectio & endung (S 0, M 1), fyllnes (S 0, M 1) & $\begin{array}{l}\text { MkArgGl } \\
\text { (Li) } 3\end{array}$ \\
\hline 61. & petra & $\operatorname{carr}(\mathrm{S} 0, \mathrm{M} 1), \operatorname{stan}(\mathrm{S} 0, \mathrm{M} 1)$ & 15.46 \\
\hline 62. & plectere & cursian (S 0, M 1), slean (S 0, M 1) & 15.17 \\
\hline 63. & praesidens & heahgerefa (S 0, M 1), undercyning (S 0, M 1) & 13.9 \\
\hline
\end{tabular}




\begin{tabular}{|c|c|c|c|}
\hline 64. & primatus & ealdormann (S 0, M 1), forwost (S 0, M 1) & $\begin{array}{l}\text { MkHeadGl } \\
\text { (Li) } 2\end{array}$ \\
\hline 65. & procella & windraes (S 0, M 1), yst (S 0, M 1) & 4.37 \\
\hline 66. & propositio & foregearwian (S 0, M 1), temesian (S 0, M 1) & 2.26 \\
\hline 67. & retro & behindan (S 0, M 1), on bace (S 0, M 1) & 8.33 \\
\hline 68. & rumor & maersung (S 0, M 1), maerpu (S 0, M 1) & 1.28 \\
\hline 69. & sapientur & snotorlice (S 0, M 1), wislice (S 0, M 1) & 12.34 \\
\hline 70. & scindere & torendan (S 0, M 1), toslitan (S 0, M 1) & 14.63 \\
\hline 71. & secessus & feltun (S 0, M 1), utgeng (S 0, M 1) & 7.19 \\
\hline 72. & semens & saedere (S 0, M 1), sawan (S 0, M 1) & 4.26 \\
\hline 73. & semita & geong (S 0, M 1), stiga (S 0, M 1) & 1.3 \\
\hline 74. & sepe & oftest ( $\mathrm{S} 0, \mathrm{M} 1)$, simble/symle (S 0, M 1) & 5.4 \\
\hline 75. & splendentia & lixan (S 0, M 1), scinan (S 0, M 1) & 9.3 \\
\hline 76. & splendor & leoht (S 0, M 1), scinnes (S 0, M 1) & 13.24 \\
\hline 77. & sternere & braedan (S 0, M 1), lecgan (S 0, M 1) & 11.8 \\
\hline 78. & stratus & bedd (S 0, M 1), sang (S 0, M 1) & 14.15 \\
\hline 79. & sufficere & wel lician (S 0, M 1), wel magan (S 0, M 1) & 14.41 \\
\hline 80. & titulus & mearc (S 0, M 1), tacn (S 0, M 1), titul (S 0, M 1) & 15.26 \\
\hline 81. & tunica & cyrtle (S 0, M 1), tunece (S 0, M 1) & 6.9 \\
\hline 82. & undique & aghwanan (S 0, M 1), from halfe aeghwilc & 1.45 \\
\hline 83. & velare & gehydan (S 0, M 1), wrigan (S 0, M 1) & 14.65 \\
\hline
\end{tabular}

C.3 Unclear order

\begin{tabular}{|l|l|l|l|}
\hline \multicolumn{1}{|c|}{ Lemma } & \multicolumn{1}{|c|}{ Interpretamenta } & \multicolumn{1}{c|}{$\begin{array}{c}\text { Relevant } \\
\text { multiple } \\
\text { gloss(es) }\end{array}$} \\
\hline 1. & adhuc & get (S 2, M 3), geona (S 1, M 3) & $\begin{array}{l}8.17,14.43, \\
14.63\end{array}$ \\
\hline 2. & amplius & forpor (S 2, M 3), leng (S 1, M 2) & $9.8,15.5$ \\
\hline
\end{tabular}




\begin{tabular}{|c|c|c|c|}
\hline 3. & cogitare & smeagan (S 3, M 2), pencan (S 1, M 2) & $1.6,2.8$ \\
\hline 4. & cognoscere & ongietan (S 6, M 2), cnawan (S 0, M 2) & $2.8,6.38$ \\
\hline 5. & condemnare & hinan (S 0, M 2), niperian (S 0, M 2) & $14.64,16.16$ \\
\hline 6. & $\begin{array}{l}\text { dimittere ('to } \\
\text { forgive') }\end{array}$ & forgiefan (S 7, M 3), forlaetan (S 0, M 3) & $2.7,3.28,11.25$ \\
\hline 7. & effundere & agietan (S 1, M 2), todalan (S 0, M 2) & $14.3,14.24$ \\
\hline 8. & eiectare & (for)drifan (S 8, M 3), (for/to)weorpan (S 6, M 2) & $1.39,7.26$ \\
\hline 9. & facere $^{\mathbf{3 1}}$ & don (S 47, M 6), wyrcan (S 12, M 6) & $\begin{array}{l}\text { 1.3, 4.32, 6.21, } \\
7.12,7.13, \\
11.17\end{array}$ \\
\hline 10. & forte & eape (S 0, M 2), wenunga (S 0, M 2) & $11.13,14.2$ \\
\hline 11. & iam & gea (S 4, M 3), sop(lice) (S 2, M 2) & $8.2,12.34$ \\
\hline 12. & interrogare & frignan/fragnian (S 25, M 4), ascian (S 1, M 3) & $8.5,13.3,15.2$ \\
\hline 13. & introire & (in)gan (S 19, M 4), (in)gangan (S 0, M 5) & $\begin{array}{l}5.12,8.26 \\
10.23,11.2\end{array}$ \\
\hline 14. & manducare & etan (S 17, M 3), brucan (S 3, M 3) & $\begin{array}{l}6.37,6.44, \\
14.14\end{array}$ \\
\hline 15. & multus & manig (S 38, M 4), felan (S 2, M 3) & $\begin{array}{l}5.26,6.34, \\
12.41\end{array}$ \\
\hline 16. & omnis & eall (S 66, M 2), aghwwilc (S 3, M 3) & $9.15,16.15$ \\
\hline 17. & profici & feran (S 1, M 2), faran (S 0, M 2) & $12.1,16.20$ \\
\hline 18. & reus & scyldig (S 0, M 2), synnig (S 0, M 2) & $3.29,14.64$ \\
\hline 19. & sequi & (after)fylgan (S 22, M 4), secan (S 0, M 4) & $\begin{array}{l}2.14,8.34 \\
10.21,10.28\end{array}$ \\
\hline 20. & servus & esne (S 1, M 2), prael (S 1, M 2) & $10.44,10.47$ \\
\hline 21. & stupere & swigian (S 1, M 2), styltan (S 0, M 2) & $1.22,6.51$ \\
\hline 22. & virtus & meaht (S 10, M 2), magen (S 2, M 2) & $9.1,13.25$ \\
\hline
\end{tabular}

\footnotetext{
${ }^{31}$ On the overlap of OE don and wyrcan, see further Kotake (2007).
} 